\title{
Investigating Polyploidy: Using Marigold Stomates \& Fingernail Polish
}

\author{
Author(s): Kimberly L. Hunter, Rebecca S. Leone, Kimberly Kohlhepp, and Richard B. Hunter \\ Source: The American Biology Teacher, 64(5):364-368. \\ Published By: National Association of Biology Teachers \\ https://doi.org/10.1662/0002-7685(2002)064[0364:IPUMSF]2.0.CO;2 \\ URL: http://www.bioone.org/doi/full/10.1662/0002-7685\%282002\%29064\%5B0364\%3AIPUMSF \\ $\% 5 \mathrm{D} 2.0 . \mathrm{CO} \% 3 \mathrm{~B} 2$
}

BioOne (www.bioone.org) is a nonprofit, online aggregation of core research in the biological, ecological, and environmental sciences. BioOne provides a sustainable online platform for over 170 journals and books published by nonprofit societies, associations, museums, institutions, and presses.

Your use of this PDF, the BioOne Web site, and all posted and associated content indicates your acceptance of BioOne's Terms of Use, available at www.bioone.org/page/terms_of_use.

Usage of BioOne content is strictly limited to personal, educational, and non-commercial use. Commercial inquiries or rights and permissions requests should be directed to the individual publisher as copyright holder. 


\section{\& Fingernail Polish}

KimBerLy L. HUNTER

Rebecca S. Leone

KIMBERLY KOHLHEPP

RICHARD B. HUNTER

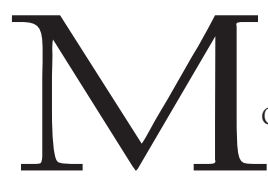

ost flowering plant species have more than two sets of chromosomes, a condition termed polyploidy (Bennett $\&$ Leitch 1997). Researchers have found that $70 \%$ or more of all flowering plants, and some $90 \%$ of ferns, contain three or more sets of chromosomes (Masterson 1994; Pichersky et al. 1990). In contrast, even one extra chromosome in an animal is debilitating or fatal. One form of Down's syndrome is caused by only one extra chromosome. Most polyploid animals, with the exception of some fish and frogs, are naturally aborted or die immediately after birth (Gardner et al. 1991). Extra sets of chromosomes in plants, however, can be advantageous, especially in agriculture.

Kimberly L. Hunter, Ph.D., is Assistant Professor; RebecCA S. LEONE and KIMBERLY KOHLHEPP are students; and RICHARD B. HUNTER is a part-time Lecturer in the Department of Biological Sciences, Salisbury University, Salisbury, MD 21801; e-mail correspondence: kxhunter@salisbury.edu.
Since the 1930s polyploidy has been investigated to try to understand its biological significance (Stebbins 1947). Some fish and frogs, some insects, and even some human tissue (e.g., cells surrounding the heart after a heart attack) are polyploid, but the causes or advantages are unclear (Bogart 1980; Schultz 1980; Herget et al. 1997). Since most plants are polyploid, they represent a useful tool for studying polyploidy and its effects.

Plant breeders attempt to use polyploidy to increase yield, improve quality, and adapt crops to particular growing conditions (Dewey 1980; Zeven 1980). The seedless watermelon and larger tetraploid grapes are examples of the utilization of polyploidy. Many other crops species are also polyploids, including coffee, cotton, potatoes, strawberries, sugar cane, tobacco and wheat (Simpson \& Ogorzaly 1995). In some instances polyploidy may result in larger flowers, seed, or fruit; increased photosynthetic and respiration rates; greater tolerance of extreme temperatures; and drought or flooding tolerance (Tal 1980). The single consistent effect of polyploidy is an 
increase in cell size (Masterson 1994; Bennett \& Leitch 1997).

Hands-on experimentation with polyploidy is a useful approach to connect research with classroom teaching. The following activity uses marigolds to explore the effects of differing chromosome number on plant cell size. Researchers have documented a correlation between plant ploidy and guard cell size, and its correlate, density (Masterson 1994). Guard cells control opening and closing of stomates on the leaf surface. Students will examine guard cell size and/or density in three different ploidy levels of marigolds (diploid, triploid and tetraploid).

This activity is designed to take the field of polyploidy and place it on a usable level for middle and high school students. This lab will allow the class and teacher to discuss complex topics, including chromosomes, cells, plant growth, the function of stomates, and how math plays a role in data collection. This activity also supports the National Science Education Standards (A: science as inquiry; C: life science; E: science and technology; F: science in personal and social perspectives, and G: history and nature of science) (National Research Council 1996). Ultimately, the goal is to have the student experience that there is much left to be discovered in science.

\section{Materials}

- Diploid (2X): 1 packet Deep Orange Lady Hybrid Marigold, Tagetes erecta

- Triploid (3X): 1 packet Nugget Supreme Yellow Marigold, Tagetes erecta $X$ Tagetes patula

- Tetraploid (4X): 1 packet Jaguar Marigold, Tagetes patula

- Potting soil

- Water
- Small paper cups (three cups for each pair of students)

- Microscopes (1 for each student or 1 for each group of 3 to 4 students)

- Microscope slides

- Masking tape

- Clear nail polish

- Forceps

- Egg cartons (three sections, or cups, for each pair of students)

Optional: For Measuring Guard Cells Technique \#2, an ocular micrometer for each microscope

Optional: A calibration slide (Available from Carolina Biological Supply Co.)

\section{Class Procedure}

Planting Procedure (time needed: approximately 20 minutes) 


\section{Allow 2 to 3 weeks for plants to mature.}

Each set of partners should fill three small paper cups with potting soil. Bury 1 to 2 diploid seeds in one cup, 1/8 inch deep. Label the cup with the type of seed along with its ploidy level planted in the cup (ex. diploid 2X Orange Lady). Repeat these steps for the triploid and tetraploid species, each in its own cup. Thoroughly water the seeds. Place the cups in a moderately warm and sunny area, or under lights if classroom windows are lacking. Within 2 to 3 days, seeds should begin to sprout. At the beginning of the class period, each day for 2 to 3 weeks, have the students collect data on the plants. For example, students could measure height, record the number of leaves, and draw a sketch of the plants.

\section{Collection \& Painting Procedure (time needed: 15 to 20 minutes)}

Using clear nail polish, students will view the guard cells on the leaf. The top of a leaf should be painted with a thin coat of polish. As the nail polish dries, it conforms to the shape of the surface of the leaf. When the polish is peeled away, it will contain a perfect imprint of every cell on the surface of the leaf. The advantage of looking at this peel under the microscope rather than the actual leaf is that the person using the microscope does not have to repeatedly focus up and down through the layers of the leaf. If the nail polish is left on the leaf long enough, it even picks up the green color of the leaf.

\section{Each pair should:}

1. Collect one lobe (a smaller leaf) from a leaf of the diploid plant.

2. Place the leaf in a section of an egg carton and label the outside of the section with the partners' names and ploidy level of the leaf. Repeat Steps 1 and 2 for triploid and tetraploid plants.

3. Paint the top of each leaf with a thin coat of CLEAR nail polish and place each leaf back into the correct section of the egg carton. Be careful not to mix up the leaves and the ploidy levels.

4. Allow the polish to dry overnight. If polish does not dry completely, it will stretch and skew measurement of guard cells.

5. Carefully peel the polish (which is now molded into the shape of the surface of the leaf) off of the leaves using forceps. This requires patience.

6. Label each slide with a small piece of masking tape. Place each peel on a different microscope slide and place a cover slip on each. Discard used leaves.
7. View each slide under a microscope. (See Figure 1 for a drawing of the view under the microscope).

8. You will see impressions of guard cells and epidermal cells. The shape of the guard cells resembles an ellipse (Figure 1). The guard cells are found in pairs and they regulate the stomatal aperture, or opening, that they surround.

\section{Measuring Guard Cells: Technique \#1 (time needed: 30 to 40 minutes)}

Students will work in pairs. Students from 8th grade and below should follow Technique \#1. Students in 9th through 12th grades should follow Technique \#2.

Students can count the number of guard cell pairs in each field of view. Larger plant cells result in fewer guard cell pairs in a field of view because the cells are farther apart. In other words, density of the guard cells is proportional to cell size in these species of marigolds. This will indirectly specify the size of the guard cells. For each leaf, students can count the guard cells in three fields of view.

\section{Each set of partners should:}

1. Look into the objective lens of the microscope. You will see a circle with elliptical-shaped cells and other lines connecting them (Figure 1). The outer circle and everything inside of it is called the field of view. The ellipses are guard cells. Count the number of guard cell pairs that you see in the circle and record that number. The epidermal cells are the ones that look like jigsaw puzzle pieces (Figure 1).

2. Move the slide a little to the right or left. You will see a new field of view.

3. Count the number of guard cells you see and record the number, again.

4. Repeat Step 2.

5. Change slides and count the number of guard cells in three fields of view for the next ploidy level.

6. Repeat Step 5 for the third ploidy level.

\section{To calculate the area of the field of view, the stu- dents should:}

1. Place a clear plastic millimeter ruler on LOW power and focus on the millimeter divisions.

2. Measure the diameter of the circular field of 
view by counting the number of millimeter divisions that can be seen within the field of view. (Estimate fractional $\mathrm{mm}$, like $1 / 2$ or $1 / 4$.)

3. Convert this number to micrometers (i.e., $1 \mathrm{~mm}=1000 \mu \mathrm{m})$. Hint: Add three zeros to the number in millimeters to find the number in micrometers.

4. To find the high power field of view, divide the magnification of the high power objective lens by the low power objective lens (i.e., 40/10).

5. Divide the diameter in micrometers of the low power field of view by the number found in Step 4.

High Power Field of View $=\frac{\text { Low Power Field of View }}{\text { High Power Obj./Low Power Obj. }}$

6. Plug the radius (diameter from Step 5 divided by 2 ) into the formula for area of a circle: $A=\Pi r^{2}$.

7. Divide the number of ellipses counted in one of the diploid fields of view by the area of the field of view to find the guard cell pair density. Multiply by $1,000,000$ to calculate number per square millimeter.

8. Repeat this process with all of the fields of view for each of the ploidy levels. The guard cell density tells us how "crowded" the guard cells are on the leaf. The bigger the guard cells, the fewer the number that will fit in a field of view.

The students can average the fields of view for each polyploidy level.

\section{Measuring Guard Cells: Technique \#2 (time needed: 30 to 40 minutes)}

Instead of counting the number of guard cells per field of view, students can also measure the ellipse the guard cells form. This will directly, rather than indirectly, show the students the relationship between the guard cell size and ploidy level. To accomplish this, the students will need an ocular micrometer, which is a ruler that fits into the eyepiece of the microscope.

\section{Each set of partners should:}

1. Place the diploid slide under the microscope.

2. Looking under the microscope at high power, students will see guard cell pairs and the ocular micrometer. Randomly select a guard cell ellipse and measure the length (L) and width (W) of the ellipse using the ocular micrometer. Rotate the ruler by twisting the eyepiece clockwise or counter-clockwise when necessary.
3. Repeat Step 2 for two more guard cell pairs.

4. Switch slides and measure 3 guard cell pairs of the triploid and tetraploid slides.

5. Use the formula for the area of an ellipse, $\mathrm{A}=\Pi(\mathrm{L} / 2)(\mathrm{W} / 2)$, to compute the area of each guard cell pair.

Students can average the areas of the guard cells for each ploidy level. Each measurement taken is in "eyepiece units." If it is possible, the measurements should be converted to micrometers using a calibration slide which is available from most biological supply companies. On a standard microscope, students should view the cells under 400X (10X eyepiece and 40X objective).

\section{To convert the measurements to "real life meas- urements":}

1. Place the micrometer slide under the microscope. Students will see two rulers. The dark one will be the ocular micrometer; the light one will be the micrometer slide. The micrometer slide lines will be much larger than the ocular micrometer because it has been magnified 400 times. Line up the two rulers one on top of the other.

2. Count the number of little lines between two of the big lines (i.e., 40 little lines between the two big lines).

3. According to the micrometer slide, from one big line to the next is $0.1 \mathrm{~mm}$ or $100 \mu \mathrm{m}$. Each ocular micrometer measurement is $100 \mu \mathrm{m}$ divided by the number of little lines the students counted.

4. Convert all of the areas of the ellipses to square micrometers by multiplying the lengths and widths by the factor measured in Step 3 and recalculate the areas.

\section{Results/Discussion}

Students should see that there is a clear difference in the area and/or density of the guard cell pairs in different ploidy levels. The students should observe from these results that the lower the density of the guard cell pairs, the larger the area of the ellipse formed by the two guard cells. In our study, the mean guard cell areas (mean \pm standard error of the mean) were calculated: Orange Lady (2X) $471.7 \mu \mathrm{m}^{2} \pm 15.3$, Yellow Nugget (3X) $570.1 \mu \mathrm{m}^{2} \pm 14.5$, and Jaguar (4X) $742.1 \mu \mathrm{m}^{2} \pm 19.4$. The mean density of guard cell pairs (per field of view) were: Orange Lady (2X) 27.9, Yellow Nugget (3X) 18.5, and Jaguar (4X) 13.4. The 
relationship between ploidy and cell size is clearly observed, and these values can serve as a standard for the investigation.

\section{Conclusion}

Possible questions for discussion might be:

1. Why do you think guard cells would be larger when plants are polyploid?

2. What would be an advantage to having polyploidy in marigolds? In other plants?

3. Why is it important to take multiple measurements?

4. What would be the problem with only taking measurements from one or two plants?

5. Create a graph that represents the data collected in your investigation.

6. What is the relationship between plant ploidy and guard cell density?

7. How can we apply this knowledge to the world around us?

\section{Acknowledgments}

We would like to mention Burpee Seed Company ${ }^{\circledR}$ for the marigold seeds of various ploidy levels they provide in their catalog. Burpee seeds can be ordered toll-free from 1-800-888-1447 or you can obtain a catalog from: Burpee Seed Co., 300 Park Ave., Warminster, PA 18991-0001. We would also like to acknowledge S. Weaver for help in the experiment and the editing of this paper, and C. Briand for editing.

\section{Glossary of Terms}

Polyploidy - a condition where the plant or animal has more than two sets of chromosomes in each cell
Diploid - a plant or animal with two sets of chromosomes (the amount most animals have)

Triploid - a plant or animal with three sets of chromosomes

Tetraploid - a plant or animal with four sets of chromosomes

\section{References}

Bennett, M.D. \& Leitch, I.J. (1997). Polyploidy in angiosperms. Trends in Plant Science, 2(12), 470-6.

Bogart, J.P. (1980). Evolutionary implications of polyploidy in amphibians and reptiles. In W.H. Lewis (Ed.): Polyploidy: Biological Relevance (pp. 341-78). New York: Plenum Press.

Dewey, D.R. (1980). Some applications and misapplications of induced polyploidy to plant breeding. In W.H. Lewis (Ed.): Polyploidy: Biological Relevance (pp. 445-470). New York: Plenum Press.

Gardner, J.E., Simmons, M.J. \& Snustad, D.P. (1991). Principles of Genetics. New York: John Wiley \& Sons.

Herget, G.W., Neuburger, M., Plagwitz, R. \& Adler, C.P. (1997). DNA content, ploidy level, and number of nuclei in the human heart after myocardial infarction. Cardiovascular Research, 36, 45-51.

Masterson, J. (1994). Stomatal size in fossil plants: Evidence for polyploidy in majority of angiosperms. Science, 264, 421-4.

National Research Council. (1996). National Science Education Standards. Washington, DC: National Academy Press.

Pichersky, E., Soltis, D. \& Soltis, P. (1990). Defective chlorophyll a/b-binding protein genes in the genome of a homosporous fern. Proceedings of the National Academy of Sciences USA, 87, 195-9.

Schultz, R.J. (1980). Role of polyploidy in the evolution of fishes. In W.H. Lewis (Ed.): Polyploidy: Biological Relevance (pp. 313-40). New York: Plenum Press.

Simpson, B.B. \& Ogorzaly, M.C. (1995). Plants in Our World. New York: McGrawHill, Inc.

Stebbins, G.L. (1947). Types of polyploids: Their classification and significance. Advanced Genetics, 1, 403-429.

Tal, M. (1980). Physiology of polyploids. In W.H. Lewis (Ed.): Polyploidy: Biological Relevance (pp. 61-75). New York: Plenum Press.

Zeven, A.C. (1980). Polyploidy and plant domestication. In W.H. Lewis (Ed.): Polyploidy: Biological Relevance (pp. 385-408). New York: Plenum Press. 